\title{
The age of black pine (Pinus nigra Arn. ssp. salzmannii (Dunal) Franco) mother trees has no effect on seed germination and on offspring seedling performance
}

\author{
Reyes Alejano ${ }^{1}$ - Marta Domínguez-Delmás ${ }^{2} \cdot$ Ignacio García-González $^{2}$ • Tomasz Wazny ${ }^{3,4}$ • Javier Vázquez-Piqué ${ }^{1}$. \\ Manuel Fernández-Martínez ${ }^{1}$
}

Received: 4 November 2018 / Accepted: 11 January 2019 / Published online: 13 February 2019

(C) INRA and Springer-Verlag France SAS, part of Springer Nature 2019

\begin{abstract}
- Key message We sampled Pinus nigra cones in 29 trees in an age range of 90 to 725 years. The mother tree age did not significantly influence the pinecone or pine seed size, seed germination capacity, or plant size or vigor displayed during the first year of growth in the nursery.

- Context Pinus nigra Arn. ssp. salzmannii is a long-lived Mediterranean species, with millenary trees residing in an old-growth forest in the Cazorla Mountain Range in SE Spain which is home to the oldest known trees in the Iberian Peninsula.

- Aims This study aimed to assess how the mother tree age in Pinus nigra influences seed viability, germination capacity, and the seedling survival and growth during the first year under nursery conditions.

- Methods Twenty-nine trees aged 90 to 725 years were selected and 60 cones were harvested per tree to study the cone characteristics (size and weight), seed viability, and germination capacity in relation to the mother tree age. Eighty germinated seeds per tree were transferred to the nursery and seedling survival and growth were measured after the first growing season.
\end{abstract}

\footnotetext{
Handling Editor: Andrew Merchant

Contribution of the co-authors Marta Domínguez Delmás took part in designing the experiment, fieldwork, and tree ring analysis for age determination, and coordinating the research project.

Ignacio-García González participated in designing the experiment and fieldwork.

Tomasz Wazny took part in designing the experiment, fieldwork, and tree ring analysis for age determination.

Javier Vázquez Piqué participated in designing the experiment and fieldwork, running the data analysis, and writing the paper.

Manuel Fernández participated in designing the experiment, supervising lab and nursery work with seeds and seedlings, running the data analysis, and writing the paper.

Reyes Alejano had the first idea, participated in designing the experiment, and field sampling. He coordinated the works in the lab (cones and seeds assessment and germination tests) and nursery (plantation and follow up of seedlings). He participated in designing the statistical analysis and writing the paper.
}

Electronic supplementary material The online version of this article (https://doi.org/10.1007/s13595-019-0801-7) contains supplementary material, which is available to authorized users.

This article is part of the topical collection on Mediterranean Pines

Reyes Alejano

ralejan@uhu.es

Extended author information available on the last page of the article 
- Results Significant between-tree differences were detected for cone characteristics (cone and seed weight, number of seeds per cone), as well as for germination capacity. Notably, however, the mother tree age did not significantly influence the aforementioned parameters. - Conclusion Forest management and regeneration practices of Pinus nigra should take into account that trees of this species up to at least 725 years old produce seeds with a fairly high reproductive capacity.

Keywords Pinus nigra $\cdot$ Aging $\cdot$ Seed viability $\cdot$ Old-growth forests

\section{Introduction}

In face of the increasing human population pressure and resource demands and of a changing global climate, management of the remaining world's old-growth forests, either for conservation, for production, or for multiple use, is a global issue of critical importance (Beadle et al. 2009; Lindenmayer and McArthy 2002). It is nowadays well understood that such forests play important roles in harboring biodiversity (Lindenmayer and Franklin 2002), and in terrestrial carbon storage and sometimes in sequestration (Carey et al. 2001). Nevertheless, there is little data on the ability of trees in old-growth forests to maintain their regeneration capacity (i.e., to produce viable seeds in enough quantity) as they may approach senescence. The regeneration phase is a key part of forest conservation and therefore of sustainable forest management (Gordo et al. 2012; Guariguata and Pinard 1998). Forest regeneration is a complex process driven by the interplay of numerous biotic and abiotic factors impacting on the life cycle stages of plants (Smith et al. 1997). The first pre-requisite for regeneration is suitable seed production, which depends on stand maturity, fertility, and masting (Lucas-Borja et al. 2012; Viglas et al. 2013). Further, natural regeneration depends not only on seed production, but also on seed germination and site conditions (Kitajima and Fenner 2000), with the seed and the seedling stages being recognized as the most important (Lucas-Borja et al., 2017; Mao et al. 2014).

The plant life cycle comprises several stages (juvenile, mature, and senescence). All of these stages are strictly coordinated by phytohormones and induced and modified by environmental factors. It is widely assumed that the senescence is generally characterized by a slowdown in metabolic activity, a decrease in apical and cambial growth, the production of smaller leaves and fewer flowers, and seeds with lower germination potential (Larcher 2003). However, as it is very difficult to know when a tree reaches senescence, this statement remains somewhat ambiguous (Stephenson et al. 2014). Although there is ongoing debate about the terminology used to describe the process, it is generally agreed that senescence can be due to aging (deterioration in performance not under the control of an endogenous biological clock) or to senescence (deterioration in performance depending directly on endogenous processes, like metabolite accumulation, that cause DNA damage) (Brutovská et al. 2013, Thomas 2013). Therefore, in order to avoid misunderstandings, in this article, the term senescence is used to define the last stage of plant life, but taken into account that it could be due to senescence, aging, or both simultaneously. Plant type differences (monocarpic vs. polycarpic; genet vs. ramet) must also be taken into account (Brutovská et al. 2013; Munné-Bosch 2008). In addition, within woody plant maturity and senescence stages, fruit production competes with vegetative growth of the supporting and photosynthetic tissues (Thomas 2013). The fertility and the reproductive capacity of perennial plants are believed to progressively increase up to a peak level, which is maintained for some years, and thereafter start decreasing or else completely disappear during the last stage of life (Larcher 2003; Müller et al. 2014). These parameters have been linked to genetic constitution, to climatic conditions, or otherwise to resource availability, yet their relationship with the mother tree age has hardly been studied (Ganatsas et al. 2008; Herrera 1991). Nonetheless, the aforementioned statements about an agedlinked decreases in reproductive capacity and fertility have been refuted by some authors, age having been considered a relative physiological parameter of plants or animals, depending on a given relative longevity (Klekovski and Godfrey 1989). As some pine species' life spans are rather long, particularly mountain habitat dwelling species (e.g., 300 to 500 years for temperate Pinus sp., 1200 years for P. cembra, 2000 to 4000 years for $P$. aristata and more than 4000 years for $P$. longaeva), it is therefore not easy to establish whether senescence has been reached (Larcher 2003; Thomas 2013).

A great mass of data has been accumulated in relation to developmental processes when animals age, especially with regard to Homo sapiens. However, little beyond conjecture has been written on the effect of aging with respect to the longest lived organisms, that is to say trees (Lanner and Connor 2001). As a matter of fact, few studies exist on the relationship between seed viability and germination capacity and mother tree age for P. nigra (Tíscar Oliver 2002) or other forest species (Ganatsas et al. 2008; Lanner and Connor 2001; Mao et al. 2014). Lannar and Connor (2001) compared putative biomarkers of aging in Great Basin bristlecone pine (Pinus longaeva D. K. Bailey) ranging in age from 23 to 4713 years. They found no significant age-related differences in xylem and phloem characteristics, annual shoot growth increments, pollen viability, seed weight, seed germinability, seedling biomass accumulation, or frequency of putative mutations. On the contrary, Tiscar Oliver (2002) found that oldest trees produced a higher quantity of empty seeds, with lighter seeds and lower germination vigor, although old trees maintained a high germination rate and 
differences with mature and young trees were not found to be significant. Therefore, the relationships between tree age and seed production and seed quality is unclear (Tiscar Oliver 2002; Müller et al. 2014; Munné-Bosch 2008; Thomas 2013).

Pinus nigra Arn. ssp. salzmannii (Dunal) Franco is a longlived Mediterranean species, with millenary trees enduring in an old growth stand located in PuertollanoCabañas, at the Cazorla Mountain Range, positioned in the South East of Spain (Creus 1998; DominguezDelmás et al. 2013). This stand constitutes the oldest known forest in the Iberian Peninsula. The inaccessibility of some areas, such as Puertollano-Cabañas, has constituted a natural self-defense for the ecosystems, later supported by protective management after the establishment of the Biosphere Reserve and Natural Park.

This study is aimed to assess how the mother tree age in Pinus nigra Arn. ssp. salzmannii influences seed viability and germination capacity, and the seedling survival and growth during the first year under controlled conditions in a nursery. We hypothesized that the oldest trees would have already entered senescence and, as a consequence, (i) the cone characteristics would show evidence of poorer reproductive performance (lower weight, fewer seeds per cone, lower seed-tocone weight fraction, higher number of empty seeds); (ii) the germination capacity in oldest trees would be lower; and (iii) the survival, growth, and vigor of seedlings under controlled conditions from seeds of oldest trees would be lower.

\section{Material and methods}

\subsection{Study area}

The study area (Puertollano-Cabañas Peak) is located in the Poyo de Santo Domingo Forest (Jaén, Spain, $37^{\circ} 49^{\prime}$ N, $2^{\circ} 57^{\prime}$ $\mathrm{W})$, home to the oldest pine trees of the Iberian Peninsula (Creus 1998). Altitude ranges from the $1700 \mathrm{~m}$ a.s.l of Puertollano to the $2028 \mathrm{~m}$ a.s.l. of the Cabañas Peak (Fig. 1). The area is contained within the Cazorla, Segura, and Las Villas Biosphere Reserve and Natural Park, with high ecological value due to the high biodiversity and the presence of endemic plant species (Dominguez-Delmás et al. 2013).

The area's main woody species comprises Pinus nigra Arn. ssp. salzmannii representing up to $97 \%$ of the forest trees. The climate is Mediterranean with a dry summer and marked differences between the minima and maxima temperatures over the year. The average annual precipitation amounts to $1100 \mathrm{~mm}$, ranging from 400 to $1900 \mathrm{~mm}$. The average annual temperature is $11.7^{\circ} \mathrm{C}$, rising from a minimum mean temperature of $4^{\circ} \mathrm{C}$ in January to a maximum mean temperature of $21{ }^{\circ} \mathrm{C}$ in August. The lithology consists mainly of limestone and dolomite.

\subsection{Tree selection, cone harvesting, and measurements}

An initial sample of 80 trees was chosen in the PuertollanoCabañas region in an area of 75 ha, in order to determine their respective ages by establishing tree ring chronologies according to standard dendrochronological procedures (DominguezDelmás et al. 2013). For the aims of this paper, 29 trees were randomly chosen from among these 80 trees. The 29 selected trees were 90 to 725 years old representing all age classes (Fig. 1, ESM Table 1).

In December of 2013, when cones were mature but seed dispersal had not started, a tree climber collected at least 60 cones from each of the 29 selected trees, while the rest of the cones were left on the trees. Cones were cold stored $\left(3^{\circ} \mathrm{C}\right)$ in the lab for 6 days and then placed in open trays at room temperature for measurement of the fresh weight of each cone. Sixty cones per tree were separated into two groups. One group of 30 cones was characterized for cone length $\left(\mathrm{L}_{\text {cone }}\right)$ and maximum diameter $\left(\mathrm{Wd}_{\text {cone }}\right)$ assessed with a caliper $( \pm$ $0.01 \mathrm{~mm}$ ). Afterwards, these 30 cones were placed into individual paper bags and further stored at room temperature (18 to $25^{\circ} \mathrm{C}$ ) and a relative humidity of 30 to $50 \%$ for a further 2 months. This first group was later used for measuring cone characteristics (see the next paragraph). The other group was left in the trays and also stored for a period of 2 months at room temperature. This second group was used for obtaining seeds for seed viability and germination tests.

In February of 2014, all cones in both groups were placed into a convection oven at $30{ }^{\circ} \mathrm{C}$ for $40 \mathrm{~h}$ to accelerate their opening. Once the cones of the first group had opened, cone mass including seeds, cone mass without seeds, and the seed mass with and without wings were recorded $( \pm 0.001 \mathrm{~g})$. The cone and seed moisture contents of a subsample were determined after oven-drying at $80{ }^{\circ} \mathrm{C}$ to a constant weight. Afterwards, dry mass per cone $\left(\mathrm{DM}_{1 \text { cone }}\right)$, number and dry mass of seeds per cone $\left(\mathrm{N}_{\text {seeds }}\right.$ and $\mathrm{DM}_{\text {seeds }}$, respectively), dry mass per seed $\left(\mathrm{DM}_{1 \text { seed }}\right)$, and the seed dry mass fraction $\left(\mathrm{SDMF}=\mathrm{DM}_{\text {seeds }} / \mathrm{DM}_{1 \text { cone }}\right)$ were calculated for each tree. For the cones of the second group, seeds were extracted and wings were removed manually; the pine seeds were stored in sealed plastic containers under cold conditions $\left(3^{\circ} \mathrm{C}\right)$, and then used for the seed viability and germination tests.

\subsection{Seed viability and germination}

When there were enough seeds, 300 seeds per tree were randomly selected from the containers of seeds to be used for the germination tests. Before starting the tests, the seeds were disinfected by immersion in a $30 \mathrm{~mL} \mathrm{~L}^{-1}$ solution of $\mathrm{H}_{2} \mathrm{O}_{2}$ for 10 min followed by mixing seeds with wetted perlite and spraying with a fungicide $\left(1.2 \mathrm{~g} \mathrm{~L}^{-1}\right.$ Captan). The mixture was placed into plastic containers under cold conditions $\left(3^{\circ} \mathrm{C}\right)$ in the 


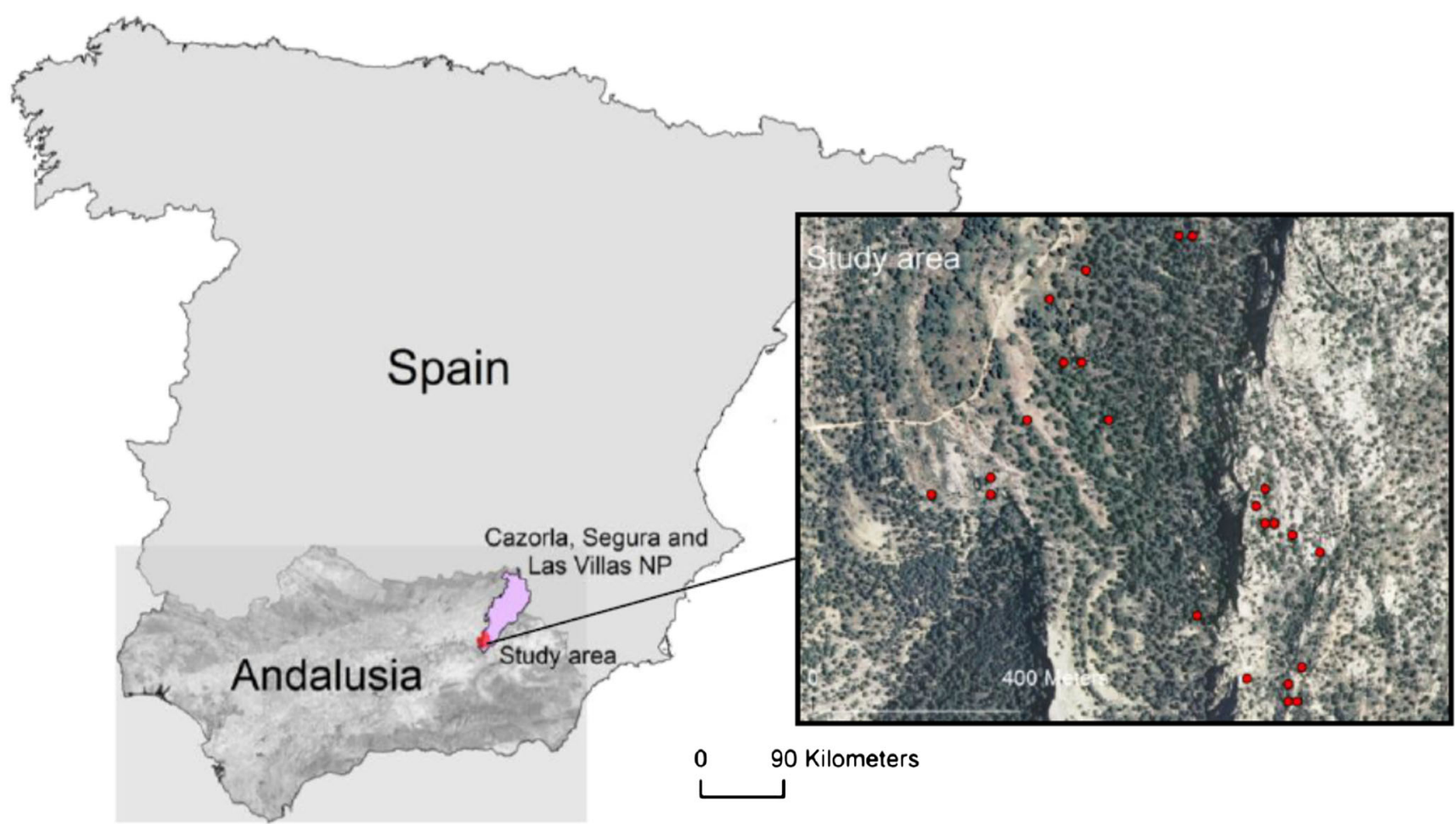

Fig. 1 Map of the Pinus nigra study area in "Poyo in Santo Domingo" forest, municipality of Cazorla (Jaén, Spain), within the Cazorla, Segura, and Las Villas Natural Park. The red circles displayed in the aerial photograph indicate the location of the 29 sampled trees, ranging from 90 to 725 years old

dark for a month. In April 2014, 200 pine seeds per tree were randomly selected and 50 pine seeds were distributed across four 8 -cm-diameter Petri dishes. These Petri dishes had been prepared beforehand by placing five sheets of absorbent paper at the bottom which had been wetted with distilled water and sprayed with fungicide. Dishes were kept at room temperature $\left(18\right.$ to $\left.25^{\circ} \mathrm{C}\right)$ exposed to a 14-h light/10-h dark photoperiod. Twice a week, for 4 weeks, germinated seed number was recorded. The germination energy (GE, defined as the percentage of the seeds germinated within the first week of analysis) and germination percentage at the end of the test (GP), as well as germination values according to Czabator and Djavanshir and Pourbeik $\left(\mathrm{GV}_{\mathrm{Cz}}\right.$ and $\mathrm{GV}_{\mathrm{DP}}$, respectively) were assessed (FAO 1985).

In 17 trees (ranging from 158 to 725 years old), an additional 30 seeds were used to perform a tetrazolium test to assay seed viability (FAO 1985). In the remaining 29-17 $=12$ trees, the cone yield in the year of collection was very small and we were unable to obtain enough seeds to perform the viability test. Before the test, the number of full and empty seeds ( $\mathrm{F}_{\text {seeds }}$ and $\mathrm{E}_{\text {seeds }}$, respectively) were counted and the percentage of full seeds was calculated $\left(\mathrm{PF}_{\text {seeds }}=100 \times \mathrm{F}_{\text {seeds }} /\left(\mathrm{F}_{\text {seeds }}+\mathrm{E}_{\text {seeds }}\right)\right)$. Empty seeds were recognized by their low weights and because they could be crushed applying a slight pressure with the fingertips. Briefly, seeds were first soaked in distilled water for $24 \mathrm{~h}$ at room temperature, and later cut in half with a scalpel. Each half seed, classified according to the tree from which it came, was immersed in a tetrazolium solution (5 $\mathrm{g} \mathrm{L}^{-1}$ of 2,3,5 triphenyl-2H-tetrazoliumchloride). Containers were stored under dark conditions for $80 \mathrm{~min}$ at
$20{ }^{\circ} \mathrm{C}$. Thereafter, viable seeds (VS, i.e., those in which embryo and nutritive tissue stained red) from each tree were counted and the following variables were calculated: percentage of viable seed fraction with respect to $\mathrm{F}_{\text {seeds }}\left(\mathrm{VS}_{\mathrm{fs}}(\%)=100 \times \mathrm{VS} / \mathrm{F}_{\text {seeds }}\right)$ and the percentage of viable seed fraction with regard to the total number of seeds $\left(\mathrm{VS}_{\mathrm{ts}}(\%)=\mathrm{VS} /\left(\mathrm{F}_{\text {seeds }}+\mathrm{E}_{\text {seeds }}\right)\right)$.

\subsection{Nursery growth of seedlings and plant quality}

The first 80 seeds that had germinated per tree $(0.5$ to $1.5 \mathrm{~cm}$ radicle length) were transferred to the nursery and planted in $250-\mathrm{cm}^{3}$ forestry containers ( 45 containers per tray, one seed per container) filled with a mixture of peat ( $75 \%$ by volume) and perlite ( $25 \%$ by volume) plus $1 \mathrm{~kg} \mathrm{~m}^{-3}$ of added Nitrofoska ${ }^{\circledR}$ blue 12-12-17 + $2 \mathrm{MgO}$ (BASF). Seedlings were sprayed with fungicide every week, and were kept wellwatered according to their needs with tap water and rainfall under a shade mesh that reduced sunlight by $30 \%$. At the end of January 2015, survival was assessed by counting the live seedlings. At the same time, the length of the epicotyl stem (EL) of all seedlings was measured.

In addition, the shoot and root dry weights (SDW and RDW, respectively, after oven-drying at $80{ }^{\circ} \mathrm{C}$ ), the total dry weight of the plant (TDW $=\mathrm{SDW}+\mathrm{RDW})$, and the shoot-toroot ratio $(\mathrm{SRDW}=\mathrm{SDW} / \mathrm{RDW})$ were determined for a sample of six seedlings per tree, evaluating a total of 8 randomly selected trees, aged 90 to 725 years drawn out of a 100-yearold range class starting at the $<100$-year age class and 
extending all the way up to the 700-800-year-old class. Furthermore, for another six seedlings from each of these eight mother trees, a root growth capacity test was performed (Fernández et al. 2007). Briefly, the test was carried out over 6 weeks (from early February to mid-March), and upon extracting seedlings out of their containers, making every possible effort to keep the root balls intact, the pre-existing white roots (usually fewer than 2 and shorter than $1 \mathrm{~cm}$ ) grown out from each ball were detached. Next, plants were transferred to 2.5-L containers filled with moistened perlite before relocation in a greenhouse with favorable temperature $\left(25 / 18{ }^{\circ} \mathrm{C}\right.$, day/night) and moisture (50/80\% relative humidity) conditions. Seedlings were watered daily and fertilized once a week, and after a 6-week growth period in the greenhouse plantlets were removed from their containers. We then measured the total length of the new roots that had emerged from the root ball as a measure of root regeneration capacity (RGC).

\subsection{Data analysis}

\subsubsection{Influence of mother tree age on cone and seed traits and germination capacity}

As a first step, we checked the significance of the between-tree variability in cone and seed traits and germination capacity by building a random effect model considering tree as a random effect. The model was:

$y_{i j}=t_{j}+e_{i j}$

where $y_{i j}$ referred to cone and seed trait or germination capacity of cone $i$ from tree $j, t_{j}$ is the tree random effect with $t_{j} \sim \mathrm{N}(0$, $\sigma^{2}{ }_{\mathrm{t}}$ ), and $e_{i j}$ is the residual error with $e_{i j} \sim \mathrm{N}\left(0, \sigma_{\mathrm{e}}^{2}\right)$. In order to satisfy the assumptions of normality, $\mathrm{N}_{\text {seeds }}$ and SDMF values were transformed to $\sqrt{\mathrm{N}_{\text {seeds }}+0.5}$ and $\arcsin \sqrt{\mathrm{SDMF}}$. We predicted for each variable the covariance parameter at tree level and checked the covariance parameter equal-to-zero hypothesis with a $\chi^{2}$ test. We also calculated the percentage of variance explained by the tree effect. This first step is relevant because, if the tree effect is not significant, it is not appropriate to check whether there are covariates at the tree level (tree age) that explain a significant part of such variability.

In a second step, for variables with a significant tree effect, we introduced the age of the tree as a covariate in a linear and quadratic form and assessed the significance of the coefficients with an $F$ test. We introduced the quadratic term to check for non-linear relationships of tree age with cone and seed traits or germination capacity.

For variables with only one value per tree $\left(\mathrm{PF}_{\text {seeds }}, \mathrm{VS}_{\mathrm{fs}}, \mathrm{VS}_{\mathrm{ts}}\right)$, a regression analysis was performed with age and age ${ }^{2}$ as independent variables. These variables were arcsin transformed.
2.5.2 Influence of mother tree age on seedling evolution and plant quality

As in Section 2.5.1, we analyzed first the between-tree variability with a random tree effect model. The variables analyzed were EL, SDW, RDW, TDW, SRDW, and RGC. For variables with significant between-tree variability (after a $\chi^{2}$ test), we introduced the age of the tree as a covariate in a linear and quadratic form. For the survival analysis, we had only one value for each of the 29 trees so we performed a regression analysis with age and age ${ }^{2}$ as independent variables, and having previously arcsin transformed the survival percentage.

\section{Results}

\subsection{Cone and seed properties}

The cone, seed size, and weight parameters showed significant differences between trees with 52 to $63 \%$ of the variance explained by the tree (Table 1$)$. The mean values (SD, range) of cone size were $\mathrm{L}_{\text {cone }}=53.7 \mathrm{~mm}(0.27,28$ to $81 \mathrm{~mm})$, and $\mathrm{Wd}_{\text {cone }}=27.3 \mathrm{~mm}(0.1,18$ to $36 \mathrm{~mm})$. The moisture content of the pinecone seeds at collection time was $14.9 \%(1.6,5$ to $40 \%)$, with no significant differences between trees $(p=0.889)$.

Tree age did not significantly influence cone or seed size, or the number of seeds per cone (Table 1). The perceived trends to lower $\mathrm{DM}_{1 \text { seed }}$ and SDMF values with increasing tree age were non-significant and had weak correlations (Fig. 2).

Seed viability analysis evidenced that on average, (a) over three quarters of all seeds were full, $\mathrm{PF}_{\text {seeds }}=78.5 \%$ (3.3), range 50 to $100 \%$; (b) a very high percentage of these full seeds were viable, $\mathrm{VS}_{\mathrm{fs}}=96.1 \%(0.8)$; (c) three quarters of all seeds were viable, $\mathrm{VS}_{\mathrm{ts}}=75.2 \%$ (3.0); and (d) none of these variables, neither $\mathrm{PF}_{\text {seeds }}$, nor $\mathrm{VS}_{\mathrm{ts}}$, nor $\mathrm{VS}_{\mathrm{ts}}$, were related to the age of the mother tree (Table 1).

Seed germination-related parameters $\left(\mathrm{GE}, \mathrm{GP}, \mathrm{GV}_{\mathrm{Cz}}\right.$, $\left.\mathrm{GV}_{\mathrm{DP}}\right)$ were highly correlated among themselves $(0.81<r<$ $0.98, p<0.001, N=17)$. The correlation between $\mathrm{GV}_{\mathrm{Cz}}$ and $\mathrm{GV}_{\mathrm{DP}}$ was so prominent $(r=0.98, p<0.001, N=17)$ that the second attribute has been omitted from Fig. 3. In the case of these four parameters, significant differences were detected between trees $(p<0.001$, Table 1$)$, the tree effect accounting for 58 to $84 \%$ of the total variability, but again the age of the mother tree was not significant (Table 1). We observed the following mean values (SD, range): $\mathrm{GE}=67.1 \%(1.9,22$ to 94); $\mathrm{GP}=76.3 \%(1.7,41.5$ to 100$) ; \mathrm{GV}_{\mathrm{Cz}}=68.0(3.9,10$ to $148)$; and $\mathrm{GV}_{\mathrm{DP}}=66.5(3.3,14.5$ to 123$)$. In the same way, the dry mass of a single seed $\left(\mathrm{DM}_{1 \text { seed }}\right)$ was positively correlated with GP and $\mathrm{GV}_{\mathrm{Cz}}(0.53<r<0.57, p<0.003, N=29)$, and SDMF with GP $(r=0.47, p=0.011, N=29)$. 
Table 1 Between-tree variability and effect of tree age on cone and seed traits and germination parameters. $\mathrm{DM}_{1 \text { cone, }}$ dry mass per cone. $\mathrm{N}_{\text {seeds }}$, number of seeds per cone. $\mathrm{DM}_{1 \text { seed }}$, dry mass per seed. $\mathrm{SDMF}=\mathrm{DM}_{\text {seeds }} / \mathrm{DM}_{1 \text { cone }}$, seed-to-cone dry mass fraction. GE, germination energy. GP, germination percentage. $\mathrm{GV}_{\mathrm{CZ}}$, germination values according to Czabator. $\mathrm{GV}_{\mathrm{DP}}$ germination value according to Djavanshir and Pourbeik. $\mathrm{PF}_{\text {seeds, }}$, percentage of full seeds. $\mathrm{VS}_{\mathrm{fs}}$, viable seed fraction as a percentage of full seeds. $\mathrm{VS}_{\mathrm{ts}}$, viable seed fraction as a percentage of total seeds

\begin{tabular}{|c|c|c|c|c|c|c|c|}
\hline \multirow[t]{2}{*}{ Variables } & \multicolumn{3}{|c|}{ Covariance parameter estimates } & \multirow{2}{*}{$\begin{array}{l}\text { Variance explained } \\
\text { by tree effect }(\%)\end{array}$} & \multirow[t]{2}{*}{$p\left(\sigma^{2}=0\right)$} & \multicolumn{2}{|c|}{ Tree age effect } \\
\hline & Tree $\left(\sigma_{t}^{2}\right)$ & Residual $\left(\sigma_{\mathrm{e}}^{2}\right)$ & Total & & & $\begin{array}{l}\text { Age } \\
(p>F)\end{array}$ & $\begin{array}{l}\operatorname{Age}^{2} \\
(p>F)\end{array}$ \\
\hline $\mathrm{DM}_{1 \text { cone }}$ & 7.28 & 4.32 & 11.60 & 63 & $<0.0001$ & 0.07 & 0.13 \\
\hline $\mathrm{N}_{\text {seeds }}$ & 2.30 & 1.37 & 3.67 & 63 & $<0.0001$ & 0.23 & 0.13 \\
\hline $\mathrm{DM}_{\text {seeds }}$ & 0.0532 & 0.0391 & 0.0923 & 58 & $<0.0001$ & 0.22 & 0.15 \\
\hline $\mathrm{DM}_{1 \text { seed }}$ & 13.10 & 12.02 & 25.12 & 52 & $<0.0001$ & 0.73 & 0.51 \\
\hline SDMF & 0.0032 & 0.0021 & 0.0053 & 61 & $<0.0001$ & 0.57 & - \\
\hline GE & 224.4 & 164.5 & 388.9 & 58 & $<0.0001$ & 0.20 & 0.31 \\
\hline GP & 221.4 & 95.8 & 317.2 & 70 & $<0.0001$ & 0.37 & 0.57 \\
\hline $\mathrm{GV}_{\mathrm{Cz}}$ & 1428.3 & 273.9 & 1702.2 & 84 & $<0.0001$ & 0.18 & 0.43 \\
\hline $\mathrm{GV}_{\mathrm{DP}}$ & 999.9 & 220.9 & 1220.8 & 82 & $<0.0001$ & 0.21 & 0.43 \\
\hline $\mathrm{PF}_{\text {seeds }}$ & & 0.0317 & & & & 0.57 & 0.42 \\
\hline $\mathrm{VS}_{\mathrm{fs}}$ & & 0.0187 & & & & 0.77 & 0.56 \\
\hline $\mathrm{VS}_{\mathrm{ts}}$ & & 0.0144 & & & & 0.75 & 0.79 \\
\hline
\end{tabular}

\subsection{Nursery growth of seedlings and plant quality}

At the end of the study period, neither plant size (EL, SDW, RDW, and TDW) nor shoot-to-root ratio (SRDW) nor the new root regeneration capacity (RGC) were significantly associated with mother tree age (Table 2). The mean total plant dry weight (TDW) was 281 (8) $\mathrm{mg}$, this varying significantly between trees $(p=0.02$, Table 2$)$. The aforementioned differences were due to the aboveground plant portion as between-tree differences in RDW were not significant $(p=0.27)$. Likewise, neither the mean EL $(7.81(0.3) \mathrm{mm})$ nor the SRDW $(0.79$ $(0.03)$ ) differed significantly between trees (Table 2$)$. As for the de novo root regeneration, while RGC $(4.80(0.82)$ $\mathrm{cm}$ ) of the newly regenerated roots differed significantly between trees $(p=0.04)$, it was also not significantly related to the mother tree age.

\section{Discussion}

For the sampled trees and corresponding age range, the average cone size ( $9.8 \mathrm{~g}$, length of $54 \mathrm{~mm}$, diameter of $27 \mathrm{~mm})$, pine seed weight $(18 \mathrm{mg})$, number of pine seeds per cone (21), and the percentage of empty pine seeds $(21.5 \%)$ were all within the average range for the species (Derridj et al. 2011; Ruiz de la Torre 2006; Tíscar Oliver 2002). Although not an objective of this study, it should be highlighted that some trees in the sample did not have sufficient production of pine cones to allow the harvest of more than 60 cones. This is common for P. nigra as being a masting species whose cone and pine seed production varies from one year to another (Tíscar and Linares 2011; Tíscar and Lucas 2010).

The between-tree differences in the parameters related to pine cone size $\left(\mathrm{DM}_{1 \text { cone }}\right)$ and seed size as well as number $\left(\mathrm{DM}_{1 \text { seed }}, \mathrm{N}_{\text {seeds }}, \mathrm{SDMF}\right)$ highlight the between-tree variability
Fig. 2 Cone and seed parameters of the 29 Pinus nigra sampled trees as a function of tree age (symbols are mean $\pm \mathrm{SE}$ ). $\mathrm{DM}_{1 \text { cone, }}$ dry mass of one cone. $\mathrm{N}_{\text {seeds }}$, number of seeds into a cone. $\mathrm{DM}_{1 \text { seed }}$, dry mass per seed. $\mathrm{SDMF}=\mathrm{DM}_{\text {seeds }} / \mathrm{DM}_{1 \text { cone }}$, seeds to cone dry mass fraction



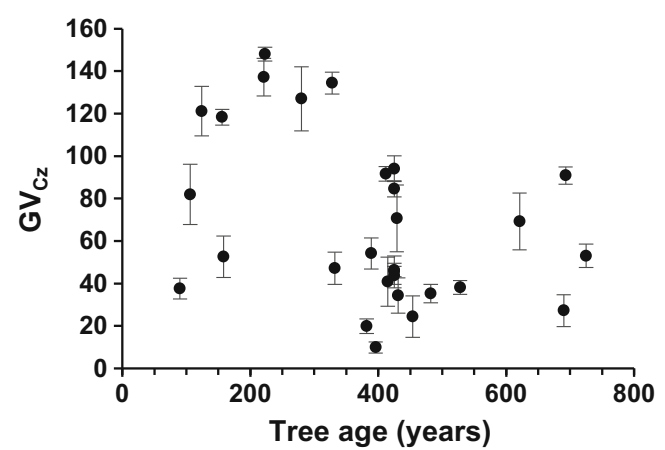

Fig. 3 Germination value $\left(\mathrm{GV}_{\mathrm{Cz}}\right)$ of Pinus nigra seeds as a function of tree age. Symbols are mean $\pm \mathrm{SE}$

which can be expected to be more greatly influenced by aspects related to genetics, physiology, or the prevailing environment of the collection year (Ayari and Khouja 2014; Tíscar Oliver 2007; Viglas et al. 2013) than the age of the mother tree. The lack of significance of tree age in the analysis of covariance is indicative of there being no evidence that these pine trees had passed beyond the stage of maturity and entered into the senescence stage, despite some trees advanced ages (Brutovská et al. 2013; Lanner 2002; Lanner and Connor 2001; Mencuccini et al. 2014). As in the case of $P$. nigra, some authors have established significant decreases in seed dry mass $\left(\mathrm{DM}_{1 \text { seed }}\right)$ coupled with increases in the number of empty seeds $\left(\mathrm{E}_{\text {seeds }}\right)$ with plant age (Ganatsas et al. 2008; Müller et al., 2014; Tíscar and Linares 2011; Tíscar Oliver 2002). Nonetheless, these same authors claimed that either the differences found were very small in absolute terms, despite being significant, and were only detected for very elderly trees at lower altitudes, and not at the altitudes of this study, 1755-1953 m a.s.l. (Tíscar and Linares 2011; Tíscar Oliver 2002), or had no effect on seed viability or seed germination (Ganatsas et al. 2008; Müller et al. 2014). This suggests that there may be some interaction between the species' reproductive performance and its environment (see also Xu et al. 2016), but this does not apply to our study since all the mother trees were from the same site, with similar climate, elevation, and coordinates notwithstanding variation attributable to microsite differences. As no trees over 725 years were sampled in this study, we are unable to extrapolate our findings to trees of more advanced ages.

With respect to the seed viability and germination capacity, the values obtained $\left(\mathrm{VS}_{\mathrm{fs}}=96 \%, \mathrm{GP}=76 \%, \mathrm{GV}_{\mathrm{Cz}}=68\right)$ also lay within the usual range for the species (Escudero et al. 1997; Lucas-Borja et al. 2011; Temel et al. 2011; Tíscar Oliver 2002). Analogous to the pinecone and pine seed sizes, the seed germination-related parameters evidenced significant betweentree differences yet were not related to the mother tree age. That is, there was no evidence of a decline in seed germination or seed viability in the oldest trees studied, as has been shown in other species (Ganatsas et al. 2008; Müller et al. 2014; Viglas et al. 2013). The positive correlation between the individual seed weight $\left(\mathrm{DM}_{1 \text { seed }}\right)$ and the germination capacity parameters (GE, GP, GV), despite presenting a moderate correlation coefficient $(0.49<r<0.57)$, have indicated a trend towards heavier seeds implying a more advanced state of development. The significant relationship between seed weight and germination parameters was not surprising, since larger seed size is generally, although not always, associated with more rapid germination (Xu et al. 2016). The latter association may be due to a greater amount of biochemical reserves, for example, proteins, involved in the germination process (Wahid and Bounoua 2013). However, our experiment was carried out under controlled conditions but, even though under natural conditions fast germination and emergence are essential for successful establishment, other seedling morphophysiological characteristics (e.g., growth rate, phenology, frost and drought resistance), as well as local conditions such as herbivores, weeds, and light, must be taken into account (Parker et al. 2006). In addition, the positive correlations of SDMF with $\mathrm{N}_{\text {seeds }}$ and GP indicate that pinecones whose weight portion contributed by the internal pine seeds was greater also tended to contain more seeds with a higher germination potential. This could be a consequence of the accumulation and activity of phytohormones, mainly auxins, during embryo and seed development (Holloway et al. 2016) that contribute to the pinecone growth when developing seeds are inside (Sauer et al. 2013).

Plant growth in the nursery, mortality, and root regeneration capacity during their first growing season were not correlated
Table 2 Between-tree variability and effect of tree age on nursery parameters. EL, length of the epicotyl stem. SDW, shoot dry weight. RDW, root dry weight. TDW, total dry weight. SRDW, shoot-to-root ratio. RGC, total length of new roots

\begin{tabular}{|c|c|c|c|c|c|c|c|}
\hline \multirow[t]{2}{*}{ Variables } & \multicolumn{3}{|c|}{ Covariance parameter estimates } & \multirow{2}{*}{$\begin{array}{l}\text { Variance explained } \\
\text { by tree effect }(\%)\end{array}$} & \multirow[t]{2}{*}{$p\left(\sigma_{\mathrm{t}}^{2}=0\right)$} & \multicolumn{2}{|c|}{ Tree age effect } \\
\hline & Tree $\left(\sigma_{t}^{2}\right)$ & Residual $\left(\sigma_{\mathrm{e}}^{2}\right)$ & Total & & & $\begin{array}{l}\text { Age } \\
(p>F)\end{array}$ & $\begin{array}{l}\mathrm{Age}^{2} \\
(p>F)\end{array}$ \\
\hline EL & 0.48 & 3.62 & 4.10 & 12 & 0.25 & & \\
\hline SDW & 176.62 & 460.11 & 636.73 & 28 & 0.02 & 0.71 & 0.6 \\
\hline RDW & 157.16 & 1206.85 & 1364.01 & 12 & 0.27 & & \\
\hline TDW & 770.89 & 2176.96 & 2947.85 & 26 & 0.02 & 0.99 & 0.77 \\
\hline SRDW & 0 & 0.03809 & 0.03809 & 0 & 1 & & \\
\hline RGC & 7.62 & 25.20 & 32.82 & 23 & 0.045 & 0.12 & 0.16 \\
\hline Survival & & 0.019 & & & & 0.26 & 0.3 \\
\hline
\end{tabular}


with the mother tree age, indicating that vigor differences were not influenced by age, at least during the first year of growth under controlled conditions. The lack of a between-tree difference in SRDW ratio points towards a similar tree biomass distribution strategy which is consequently more linked to the microsite environment (Parker et al. 2006), and less to the mother tree age or the individual. Nonetheless, the between-tree differences in SDW and root regeneration did indicate between-tree differences in vigor, likely linked to the trees physiological states reflected in the diverse reserve accumulations and growth rates (Fernández et al. 2007; Fernández et al. 2008), as neither was correlated with seed size. The root regeneration test is considered a good indicator for estimating the general plant physiological state and the plant quality index (Andivia et al. 2011; Davis and Jacobs 2005). Under favorable controlled conditions, seedling growth and biomass allocation can be more or less independent of seed size, but under unfavorable conditions (common under natural conditions) large seeds could have an advantage if they contain more biochemical reserves and produce larger seedlings (Parker et al. 2006; Xu et al. 2016). Tíscar Oliver (2002) as well as Tíscar and Lucas (2010) obtained a positive relationship between seed weight and plant biomass, possibly as they used weights of individual seeds or else of small pine seed groups in their analysis, either of which provide greater accuracy than tree averages as used in our study. In addition, seed weight differences between pinecones of the same tree can bring about additional variation, further masking the tree influence (Tíscar and Lucas 2010), and this may have occurred in our study. The plant sizes obtained at the end of the study lay within the normal range for the species (Tíscar Oliver 2002), except perhaps a little low for the epicotyl stem length, yet showed high values of biomass accumulation, especially with respect to the root system.

As a final consideration, in this study, we did not analyze the total cone production per tree or the masting behavior of the species in the area, or the synchronization of cone and seed production between trees. To do so, we would need to follow the tree cone production for several years. Such monitoring would provide interesting information about the synchronization of masting. If there is lack of synchronization between trees in seed production, this could be confounding the effect of mother tree age on reproductive ability.

\section{Conclusions}

For the Pinus nigra tree sample in an age range of 90 to 725 years, the mother tree age did not significantly influence the pinecone or pine seed size, seed germination capacity or plant size or vigor displayed during the first year of growth in the nursery. Therefore, a natural regeneration system's first requirements, namely, the production of viable seeds of sufficient quality, as well as the seed's ability to germinate and to produce potentially vigorous plants, were not affected by the mother tree age, all of which should be taken into account with respect to the management and the administration of this natural Pinus nigra old-growth forest system.

Significant differences between trees were detected, evidencing either variability in genetic composition or a determined physiological condition present in the collection year or else of the microenvironment of the individual trees. The size of cones and seeds, and the seed viability and germination capacity, as well as the characteristics of the plants raised in the nursery all fell within the normal range for this species, despite having sampled trees of an advanced age. That is, no drop in reproductive vigor was detected and nor were symptoms of aging identified in the trees sampled. This constitutes valuable information for Pinus nigra old-growth forest management practices.

Acknowledgements We thank Teresa Moro and Valentín Badillo (from the Natural Park Forest Service, Junta de Andalucía, Spain) for providing the sampling permits required for the area and for their interest in the project. The dendrochronological fieldwork for this research was partially funded by the Netherlands Organisation for Scientific Research (NWOnumber 236-61-001) and by the Spanish Ministry of Science, Innovation and Universities (Plan I+D+i AGL2017-83828-C2-2-R) and FEDER funds. We thank Antonio Jesús López- Soroche and Juan Manuel Castellano, students at the University of Huelva, Spain; Aldo Carrasco from the University Arturo Prat, Chile; and Ana J. Moreno, Y. Ramírez and Salvador Sarabia, from the University of Chapingo, Mexico, for their help with the lab and nursery work.

Funding The dendrochronological fieldwork of this research was funded by the Netherlands Organisation for Scientific Research (NWO-number 236-61-001) and National Geographic Society (Waitts Grant W 329-14). The University of Huelva, Spain, provided the lab and nursery with the needed material to perform the experiment.

Data availability The datasets generated during and/or analyzed during the current study are available from the corresponding author on reasonable request.

\section{Compliance with ethical standards}

Conflict of interest The authors declare that they have no conflicts of interest.

\section{References}

Andivia E, Fernández M, Vázquez-Piqué J (2011) Autumn fertilization of Quercus ilex ssp. ballota (Desf.) Samp.nursery seedlings: effects on morpho-physiology and field performance. Ann ForSci 68(3):543553. https://doi.org/10.1007/s13595-011-0048-4

Ayari A, Khouja ML (2014) Ecophysiological variables influencing Aleppo pine seed and cone production: a review. Tree Physiol. 34 (4):426-437. https://doi.org/10.1093/treephys/tpu022

Beadle C, Duff G, Richardson A (2009) Old forests, new management: the conservation and use of old growth forests in the $21^{\text {st }}$ century. For Ecol Manag 258(4):339-340

Brutovská E, Sámelová A, Dušička J, Mičieta K (2013) Ageing of trees: application of general ageing theories. Ageing Res Rev 12(4):855866. https://doi.org/10.1016/j.arr.2013.07.001 
Carey EV, Sala A, Keane M, Callaway RM (2001) Are old forests underestimated as global carbon sinks? Glob Change Biol 7(4):339-344

Catalán G (1993) Semillas de árboles y arbustos forestales. Ministerio de Agricultura, Pesca y Alimentación. ICONA, Madrid, p 392 ISBN: 84-8014-007-0

Creus J (1998) A propósito de los árboles más viejos de la España peninsular: los Pinus nigra Arnold subsp. salzmannii (Dunal) Franco de Puertollano-Cabañas Sierra de Cazorla, Jaén. Montes 54:68-76

Davis AS, Jacobs DF (2005) Quantifying root system quality of nursery seedlings and relationship to outplanting performance. New For 30(2-3):295-311. https://doi.org/10.1007/s11056-005-7480-y

De Aranda G (1990) Los Bosques Flotantes: historia de un roble del siglo XVIII. Colección Técnica, Ministerio de Agricultura, Pesca y Alimentación. ICONA, Madrid, p 231 ISBN: 84-85496-50-7

De la Cruz E (1994) La destrucción de los Montes (claves históricojurídicas). Universidad Complutense de Madrid, Madrid, p 287 ISBN: 84-86926-70-X

Derridj A, Abdelli D, Adjaoud D, Asmani A, Fady B, Hedjam H, LarbiAidrous N, Zanndouche O, Krouchi F (2011) A synthesis on several years study on Pinus nigra ssp mauretanica in Algeria. In: Abstract Book. Medpine 4: 4th International Conference on Mediterranean Pines. June, 6-10, 2011. Avignon, France O8-2, p 76

Dominguez-Delmás M, Alejano R, Wazny T, García-González I (2013) Radial growth variations of black pine along an elevation gradient in the Cazorla Mountains (South of Spain) and their relevance for historical and environmental studies. Eur J For Res 132(4):635652. https://doi.org/10.1007/s10342-013-0700-7

Escudero A, Barrero S, Pita JM (1997) Efects of high temperatures and ash on seed germination of two Iberian pines (Pinus nigras $\mathrm{sp}$ salzmannii, P sylvestris var iberica). Ann Sci For 54(6):553-562

FAO (1985) A guide to forest seed handling. FAO forestry paper 20/2.Ed. Food and Agriculture Organization of the United Nations, Rome Available at: http://www.fao.org/docrep/006/ad232e/AD232E09. htm. ISBN 92-5-102291-7

Fernández M, Marcos C, Tapias R, Ruiz F, López G (2007) Nursery fertilization affects the frost-tolerance and plant quality of Eucalyptus globulus Labill. cuttings. Ann. For Sci 64(8):865-873. https://doi.org/10.1051/forest:2007071

Fernández M, Alejano R, Domínguez L, Tapias R (2008) Temperature controls cold hardening more effectively than photoperiod in four Mediterranean broadleaf evergreen species. Tree For Sci Biotechnol 2(1):43-49

Ganatsas P, Tsakaldimi M, Thanos C (2008) Seed and cone diversity and seed germination of Pinus pinea in Strofylia site of the Natura 2000 network. Biodivers Conserv 17(10):2427-2439. https://doi.org/10. 1007/s10531-008-9390-8

Gordo J, Calama R, Pardos M, Bravo F, Montero G, (Eds) (2012) La regeneración natural de los pinares en los arenales de la meseta castellana. In: Instituto Universitario de Investigación en Gestión Forestal Sostenible (Universidad de Valladolid-INIA). Valladolid. 254 p. ISBN: 978-84-615-9823-6

Guariguata MR, Pinard MA (1998) Ecological knowledge of regeneration from seed in neotropical forest trees: implications for natural forest management. For Ecol Manag 112(1-2):87-99

Herrera CM (1991) Dissecting factors responsible for individual variations in plant fecundity. Ecology 72(4):1436-1448

Holloway DM, Brook B, Kang JH, Wong C, Wu M (2016) A quantitative study of cotyledon positioning in conifer development. Botany 94(11):1063-1074. https://doi.org/10.1139/cjb-2015-0242

Kitajima K, Fenner M (2000) Ecology of seedling regeneration. Seeds: the ecology of regeneration in Plant Communities. CAB International, Wellington, p 410

Klekovski EJ, Godfrey PJ (1989) Ageing and mutation in plants. Nature 340:389-391

Lanner RM (2002) Why do trees live so long? Ageing Res Rev 1(4):653-671
Lanner RM, Connor KF (2001) Does bristlecone pine senesce? Exp Gerontol 36(4-6):675-685

Larcher W (2003) Physiological plant ecology: ecophysiology and stress physiology of functional groups. Springer-Verlag, Berlin, p 513

Lindenmayer DB, Franklin JF (2002) Conserving forest biodiversity. A Comprehensive Multiscaled Approach. Island Press, Washington DC, p 351

Lindenmayer DB, McArthy MA (2002) Congruence between natural and human forest disturbance: a case study for Australian montane ash forest. For Ecol Manag 155(1-3):319-335

Lucas-Borja ME, Fonseca T, Parresol B, Silva-Santos P, García-Morote FA, Tíscar-Oliver PA (2011) Modelling Spanish black pine seedling emergence: establishing management strategies for endangered forest areas. For Ecol Manag 26(2):195-202. https://doi.org/10.1016/j. foreco.2011.03.023.

Lucas-Borja ME, Fonseca TF, Lousada JL, Silva-Santos P, García EM, Abellán MA (2012) Natural regeneration of Spanish black pine [Pinus nigra Arn. ssp. salzmannii (Dunal) Franco] at contrasting altitudes in a Mediterranean mountain área. Ecol Res 27(5):913921. https://doi.org/10.1007/s11284-012-0969-x

Lucas-Borja ME, Candel-Pérez D, Onkelinx T, Fule PZ, Moya D, Gómez R, de las Heras J (2017) Early Mediterranean pine recruitment in burned and unburned Pinus nigra Arn. ssp. salzmannii stands of Central Spain: influence of species identity, provenances and postdispersal predation. For Ecol Manag 390:203-211. https://doi.org/ 10.1016/j.foreco.2017.01.026

Mao P, Han G, Wang G, Yu J, Shao H (2014) Effects of age and stand density of mother trees on early Pinus thunbergii seedling establishment in the coastal zone, China. Sci World J 2014(468036):9. https://doi.org/10.1155/2014/468036

Mencuccini M, Oñate M, Peñuelas J, Rico L, Munné-Bosch S (2014) No signs of meristem senescence in old Scots pine. J Ecol 102(3):555565. https://doi.org/10.1111/1365-2745.12219

Müller M, Siles L, Cela J, Munné-Bosch S (2014) Perennially young: seed production and quality in controlled and natural populations of Cistus albidus reveal compensatory mechanisms that prevent senescence in terms of seed yield and viability. J Exp Bot 65(1):287-297. https://doi.org/10.1093/jxb/ert372

Munné-Bosch S (2008) Do perennials really senesce? Trends Plant Sci 13(5):216-220

Parker WC, Noland TL, Morneault AE (2006) The effects of seed mass on germination, seedling emergence, and early seedling growth of eastern white pine (Pinus strobus L.). New For 32(1):33-49. https:// doi.org/10.1007/s11056-005-3391-1

Ruiz de la Torre J (2006). Mayor F (ed) Organismo Autónomo Parque Naturales. DGCONA. Ministerio de Medio Ambiente. Madrid. Spain. 1756 p. ISBN: 10: 84-8014-660-5

Sauer M, Robert S, Kleine-Vehn J (2013) Auxin: simply complicated. J Exp Bot 64(9):2565-2577. https://doi.org/10.1093/jxb/ert139

Serrada R, Domínguez S, Sánchez MI, Ruiz J (1994) El problema de la regeneración natural del Pinus nigra Arn. Montes 36:52-57

Smith DM, Larson BC, Kelty MJ, Ashton PMS (1997) The practice of silviculture: applied forest ecology. John Wiley and Sons, New York, p 537

Stephenson NL, Das AJ, Condit R, Russo SE, Baker PJ, Beckman NG, Coomes DA, Lines ER, Morris WK, Rüger N, Álvarez E, Blundo C, Bunyavejchewin S, Chuyong G, Davies SJ, Duque Á, Ewango CN, Flores O, Franklin JF, Grau HR, Hao Z, Harmon ME, Hubbell SP, Kenfack D, Lin Y, Makana JR, Malizia A, Malizia LR, Pabst RJ, Pongpattananurak N, Su SH, Sun IF, Tan S, Thomas D, van Mantgem PJ, Wang X, Wiser SK, Zavala MA (2014) Rate of tree carbon accumulation increases continuously with tree size. Nature 507:90-93. https://doi.org/10.1038/nature12914

Temel F, Gülcü S, Ölmez Z, Göktürka A (2011) Germination of Anatolian black pine (Pinus nigra subsp. pallasiana) seeds from 
the lakes region of Turkey: geographic variation and effect of storage. Not Bot Horti Agrobo 39(1):267-274

Thomas H (2013) Senescence, ageing and death of the whole plant. New Phytol 197(3):696-711. https://doi.org/10.1111/nph.12047

Tíscar Oliver PA (2002) Capacidad reproductiva de Pinus nigra subsp. salzmannii en relación con la edad de la planta madre. Invest Agr: Sist Recur For 11(2):357-371

Tíscar Oliver PA (2007) Dinámica de regeneración de Pinus nigra ssp. salzmannii al sur de su área de distribución: etapas, procesos y factores implicados. Invest Agr: Sist Recur For 16(2):124-135

Tíscar PA, Linares JC (2011) Pinus nigra subsp. salzmannii forests from Southeast Spain: using structure and process information to guide management. Chapter 11, 27 p. In: Frisiras CT (ed) Pine Forests: types, threats and management. Nova Science Publishers Inc. ISBN: 978-1-61324-493-7

Tíscar PA, Lucas JC (2010) Seed mass variation, germination time and seedling performance in a population of Pinus nigra subsp. salzmannii. For Syst 19(3):344-353. https://doi.org/10.5424/fs/ 2010193-9094

Viglas JN, Brown CD, Johnstone JF (2013) Age and size effects on seed productivity of northern black spruce. Can J For Res 43(6):534-543. https://doi.org/10.1139/cjfr-2013-0022

Wahid N, Bounoua L (2013) The relationship between seed weight, germination and biochemical reserves of maritime pine (Pinus pinaster Ait.) in Morocco. New For 44(3):385-397. https://doi.org/10.1007/ s11056-012-9348-2

Xu Y, Cail N, He B, Zhang R, Zhao W, Mao J, Duan A, Li Y, Woeste K (2016) Germination and early seedling growth of Pinus densata Mast. provenances. J For Res 27(2):283-294. https://doi.org/10. 1007/s11676-015-0186-x

Publisher's note Springer Nature remains neutral with regard to jurisdictional claims in published maps and institutional affiliations.

\section{Affiliations}

\section{Reyes Alejano ${ }^{1}$ - Marta Domínguez-Delmás ${ }^{2}$ Ignacio García-González ${ }^{2}$ - Tomasz Wazny ${ }^{3,4}$ • Javier Vázquez-Piqué ${ }^{1}$. Manuel Fernández-Martínez}

Marta Domínguez-Delmás

mardodel@gmail.com

Ignacio García-González

nacho.garcia.glez@gmail.com

Tomasz Wazny

twazny@email.arizona.edu

1 Agroforestry Sciences Department, University of Huelva, Campus El Carmen, 21071 Huelva, Spain

2 Department of Botany, University of Santiago de Compostela, Rua Benigno Ledo s/n, Escuela Politécnica Superior, Campus de Lugo, 27002 Lugo, Spain
Javier Vázquez-Piqué

jpique@uhu.es

Manuel Fernández-Martínez

manuel.fernandez@dcaf.uhu.es

3 Nicolaus Copernicus University, Institute for the Study, Conservation and Restoration of Cultural Heritage, ul. Sienkiewicza 30/32, 87-100 Toruń, Poland

4 Tree Ring Lab, University of Arizona, 1215 Lowell St., Tucson, AZ, USA 